\title{
Observations on the biology of Hormosianoetus mahunkai Eraky and Shoker, 1993 (Acari: Histiostomatidae)
}

\author{
Azza A. Mohamed \\ Plant Protection Research Institute, A.R.C., Dokki, Giza, Egypt, azza.abdelgawad@yahoo.com.
}

\begin{abstract}
This study was conducted to throw lights on the effect of food types on the biological aspects of Hormosianoetus mahunkai Eraky and Shoker, collected from a culture of fungus, Fusarium oxysporum. Generation period as well as female life span, and fecundity were recorded when reared on dry yeast granules, wheat germ and $F$. oxysporum separately at $27+2{ }^{\circ} \mathrm{C}$ and $85+5 \%$ R.H.. The longest female Life cycle of was when fed on F. oxysporum (4.450 days) while the shortest was recorded for males when fed on dry yeast granules (2.760 days). Females lived shorter than males and its fecundity recorded the highest number of deposited eggs when fed on dry yeast granules (181.000 eggs with daily rate $12.800 \mathrm{egg} /$ day) followed by Wheat germ and F. oxysporum (158.500 and $144.500 \mathrm{eggs}$ ), respectively.
\end{abstract}

Key words: Acari, Histiostomatidae, Hormosianoetus mahunkai, biology.

\section{INTRODUCTION}

Histiostomatidae (= Anoetidae, Oudemans, 1904), is one of the Astigmata largest families with about 500 species of 58 genera (Kurosa\&Tagami 2006; OConnor 2009), and commonly inhabits the wet microhabitats. Some acaroid and anoetoid (Acaroidea, Anoetoidea) mites under unfavorable life conditions changed to hypopus specimens to adapt for the spreading and survival (Behura, 1957; Eraky, 1987; Chmielewski, 1971, 1977; Hughes, 1976; Kuo and Nesbitt, 1970; Wallace, 1960). The ecological and biological studies of this mites group are rare world, is likely due to the difficulty understanding (Bongers, et. al 1985).

The phortetic mites of the family Histiostomatidae have been frequently collected from various species of insects (prevailing Diptera and Coleoptera) (Scheucher 1957; Hughes \& Jackson 1958; Mahunka 1972; Samšiňak 1984, 1989; Mašan \& Krištofik 1992), and soil or litter samples, decaying vegetables, mushrooms, fruits and animal faces (Kazumi and Yasumasa, 2005), furthermore, found associated with stored grain, seeds of different crops . Histiostoma halicticola species was found with high population on the ground-nesting phoretic on the solitary bee, Halictus sexcinctus (Fain \& Erteld, 1998). On the other hand, the histiostomatid mites were observed feeding on the fungi growing on grain dust and decaying organic debris confirm an adequate food supply for mites in empty granaries (Muhammad, et al. 2000). In Egypt Knowledge concerning about the Acaridides fauna is few as compared to other groups of mites. Moreover, several taxa were found to be new and several morphological characteristics were described. Many species and few genera belonging to the Acaridida mites were recorded in Upper Egypt by Eraky (1992; 1994 a, b; 1997; 1998; 1999 a, b, c; 2000 a, b); Eraky and Shoker (1993 a, b; 1994); Eraky and Osman (2008 a, b, c); Fakeer et al. (2014) and Eraky et al. (2017). Although, histiostomatid mites have been identified as pests of many hosts studies began by histiostomatid mite fauna of cattle dung with the view that some of these mites may have potential importance either as actual dung decomposers or as predators or parasites of dung inhabiting fly larvae. They noticed that some species in the family Histiostomatidae are known to feed on fly eggs and larvae, for example Histiostoma laboratorium Hughes, 1950, which is associated with Drosophila cultures. Information about life cycle of histiostomatid mite species was described as possible by Hughes \& Jackson (1958) and Scheucher (1957). Since that time, the studies have concentrated on descriptions of new taxa.

The biological study on this family is rare. So, the present work aimd to study the effect of different food types (dry yeast granules, wheat germ and F. oxysporum) on the biological aspects of the mite, H. mahunkai which erected by Eraky and Shoker, (1993) from uprooted banana suckers at $27+2^{\circ} \mathrm{C}$. and $85+5 \%$ R.H.

\section{MATERIALS AND METHODS}

\section{Stock colonies of $\boldsymbol{H}$. mahunkai}

Individuals of $H$. mahunkai were collected from $F$. oxysporum cultured in plant pathology department, Shandaweel Agricultural Research Station, Agricultural Research Center (ARC), Sohag, Egypt, and then cultured in the laboratory. Two types of plastic cells containing a floor of plaster of pairs (gypsum: clay: charcoal) with percent of (6:3:1), respectively filled on the bottom of cages to depth of $0.5 \mathrm{~cm}$. Its bottom was scratched by using a needle to make convexo-concaved areas used as shelters and was suitable sites for histiostomatid mites rearing and laying eggs (Zaher et al. 1981) and (Hassan et al., 2014). The big rearing cells $2.5 \mathrm{~cm}$ diameter and $2 \mathrm{~cm}$ deep were used for laboratory culture. The small ones 
were $1 \mathrm{~cm}$ diameter and $0.8 \mathrm{~cm}$ deep was used in the biological experiments. A glass cover was used for each cell to prevent mites escape.

Histiostomatid mites cultures were kept in big rearing cells representing three major groups according to tested food (dry yeast granules, wheat germ and $F$. oxysporum ) under laboratory conditions $\left(27+2{ }^{\circ} \mathrm{C}\right.$ and $85+5 \%$ R.H.). Ten adults (female and male) were placed in rearing chamber and provided with experimental food mentioned above, with adding few drops of water by using minuten probe as source of humidity and then placed in an incubator for investigated every $12 \mathrm{~h}$, each rearing chamber was supplied with food types and water at needed

Mite larvae were reared individually on each feeding source in big cells and observed every $12 \mathrm{~h}$. until maturation. As soon as females emerged, males were introduced for mating. Eggs were collected during 12 hours. Eggs were solitary placed into small rearing cells with the aid of camel hair brush and incubated at the same conditions mentioned above. Forty fresh eggs of the same age (one-day old) were used per each rearing material and observed every 6 h. until hatching and mites become mature. Eggs laid by each female mite were counted daily until female died. At each rearing diets, the incubation period, immature stages, life cycle, longevity of both males and females, and fecundity (total number of eggs laid per female) were calculated. Experiments on the fecundity and longevity of the $H$. mahunkai were undertaken. Identification of specie was carried out by Prof. Dr. Sayed Eraky, Department of Plant Protection, Faculty of Agriculture, Assiut University, Assiut, Egypt.

\section{Statistical analysis:}

The data was subjected to analysis of variance (ANOVA) and the means were separated using Least Significant Difference (LSD).

\section{RESULTS AND DISCUSSION}

The biological aspects of $H$. mahunkai have been affected by food types under laboratory conditions $\left(27 \pm 2^{\circ} \mathrm{c}\right.$ and $\left.85 \pm 5 \mathrm{RH} \%\right)$. The developmental stages were egg, larva, protonymph, heteromorphic deutonymph (hypopi), tritonymph and adult. In similar data in the same sub-ordere astigmata Houck and OConnor (1991) use the term heteromorphic deutonymph instead of hypopus to refer to this specialized, facultative stage. The two nymphal nymphal stages are easily separated, since the protonymphs have two, while the tritonymph have four genital suckers, The results demonstrated that the first three stages (larval, protonymphal and tritonymph) of this mites were active and feed with a quiescent period prior to molting for each stage (Eraky, 1987). Members of the H. mahunkai mite showd a considerable variation in their feeding habits when fed on dry yeast granules; wheat germ and $F$. oxysporum fungus. There are interesting biological feature of $H$. mahunkai is an a parity phenomenon, i.e. the development of progeny (various stages- eggs, larvae, nymphs, including hypopi, except imagines) inside the body of dead females (as opposed to normal development outside the female body i.e. viviparity); in this case the hatching larvae and other developing juvenile specimens use the internal mother's tissues as food. This result was described previously on species in the same sub-order Astigmata by (Lipa and Chmielewski, 1966; Chmielewski and Lipa, 1967; Chmielewski, 2003). A parity has been reported long time ago in other species representatives of other mite groups, e.g. in Oribatida (Vitzthum, 1943).

\section{Incubation period and hatching.}

Females deposited their eggs singly or in scattered pattern and covered it by its food, these eggs are whitish then become creamy before hatching.

Egg incubation period was noticed when the females fed on dry yeast granules, wheat germ and F. oxysporum lasted $1.000,1.175$ and 1.275 days, respectively, while that of males lasted $1.000,1.125$ and 1.210 days. The statistical analysis of obtained data showed that L.S.D. at $0.05=(0.1902$ and 0.1758$)$ for female and male, respectively. Results similar Eraky, (1987) conducted the Incubation period of Caloglyphus berlesei were 1.5 days at $28^{\circ} \mathrm{C}$ when fed on yeasted Drosophilla.

\section{Immature stages.}

Both of H. mahunkai male and female pass through three active developmental stages (larva, protonymph, tritonymph) before reaching adult. Each active stage is followed by quiescent). Significant differences occurred between the individuals when fed on dry yeast granules; wheat germ and $F$. oxysporum average 1.973, 2.316 and 3.175 days, respectively for female. Table (1) male followed similar results

\section{Life cycle:}

Concerning life cycle duration (egg, larva, protonymph, and tritonymph), is completed with the appearance of adults. Data in table (1) showed that differed significantly on different diets on the life cycle of H. mahunkai females and males. It was longer when females and males reared on F. oxysporum followed by wheat germ and dry yeast granules $(4.450,3.491$ and 2.973$)$ days, and (3.990, 3.268 and 2.760$)$ days with L.S.D. at 0.05 level $=0.3439$ and 0.5146 , respectively.

Generally, male immatures had shorter life cycle than these of female. Similar results were obtained by 
Table (1): Duration in days of $H$. mahunkai immature stages, when fed on different diets at $27 \pm 2{ }^{\circ} \mathrm{C}$ and $85+5 \%$ R.H.

\begin{tabular}{|c|c|c|c|c|c|c|c|c|c|}
\hline \multirow{3}{*}{ Biological aspe } & & \multicolumn{4}{|c|}{ Female } & \multicolumn{4}{|c|}{ Male } \\
\hline & & \multicolumn{3}{|c|}{ Diet } & \multirow[b]{2}{*}{$\begin{array}{c}\text { LSD } \\
0.05\end{array}$} & \multicolumn{3}{|c|}{ Diet } & \multirow[b]{2}{*}{$\begin{array}{l}\text { L.S.D. } \\
\text { at } 0.05\end{array}$} \\
\hline & & $\begin{array}{c}\text { Dry yeast } \\
\text { granule }\end{array}$ & Wheat germ & $\begin{array}{c}F . \\
\text { oxysporum } \\
\end{array}$ & & $\begin{array}{c}\text { Dry yeast } \\
\text { granule }\end{array}$ & Wheat germ & $\begin{array}{c}F . \\
\text { oxysporum }\end{array}$ & \\
\hline Inc. period & & $1.000 \pm 0.05^{\mathrm{a}}$ & $1.175 \pm 0.07^{\mathrm{ab}}$ & $1.275 \pm 0.08^{\mathrm{a}}$ & 0.1902 & $1.0 \pm 0.06^{\mathrm{b}}$ & $1.125 \pm 0.08^{\mathrm{ab}}$ & $1.21 \pm 0.07^{\mathrm{a}}$ & 0.1758 \\
\hline \multirow[b]{2}{*}{ Larva } & $\mathrm{A}$ & $0.375 \pm 0.04^{\mathrm{b}}$ & $0.425 \pm 0.05^{\mathrm{b}}$ & $0.575 \pm 0.04^{\mathrm{a}}$ & 0.1425 & $0.35 \pm 0.04^{\mathrm{b}}$ & $0.4 \pm 0.04^{\mathrm{b}}$ & $0.57 \pm 0.05^{\mathrm{a}}$ & 0.1456 \\
\hline & Q & $0.228 \pm 0.01^{\mathrm{b}}$ & $0.296 \pm 0.03^{\mathrm{b}}$ & $0.475 \pm 0.02^{\mathrm{a}}$ & 0.08404 & $0.216 \pm 0.01^{\mathrm{b}}$ & $0.288 \pm 0.04^{\mathrm{ab}}$ & $0.36 \pm 0.04^{\mathrm{a}}$ & 0.0840 \\
\hline \multirow{2}{*}{ Protonymph } & A & $0.325 \pm 0.04^{\mathrm{b}}$ & $0.425 \pm 0.06^{\mathrm{b}}$ & $0.8 \pm 0.07^{\mathrm{a}}$ & 0.1732 & $0.318 \pm 0.04^{\mathrm{b}}$ & $0.4 \pm 0.07^{\mathrm{b}}$ & $0.74 \pm 0.09^{\mathrm{a}}$ & 0.2080 \\
\hline & Q & $0.220 \pm 0.01^{\mathrm{b}}$ & $0.26+0.03^{\mathrm{b}}$ & $0.375 \pm 0.04^{\mathrm{a}}$ & 0.08913 & $0.2 \pm 0.01^{\mathrm{b}}$ & $0.205 \pm 0.02^{\mathrm{b}}$ & $0.34 \pm 0.03^{\mathrm{a}}$ & 0.0594 \\
\hline \multirow{2}{*}{ Tritonymph } & $\mathrm{A}$ & $0.525 \pm 0.07^{\mathrm{a}}$ & $0.55 \pm 0.06^{\mathrm{a}}$ & $0.6 \pm 0.04^{\mathrm{a}}$ & 0.1572 & $0.45 \pm 0.06^{\mathrm{a}}$ & $0.525 \pm 0.06^{\mathrm{a}}$ & $0.58 \pm 0.06^{\mathrm{a}}$ & 0.2037 \\
\hline & $\mathrm{Q}$ & $0.300 \pm 0.02^{\mathrm{a}}$ & $0.36 \pm 0.04^{\mathrm{a}}$ & $0.35 \pm 0.04^{\mathrm{a}}$ & 0.1029 & $0.226 \pm 0.19^{\mathrm{b}}$ & $0.325 \pm 0.04^{\mathrm{a}}$ & $0.35 \pm 0.03^{\mathrm{a}}$ & 0.0728 \\
\hline Total immature & & $1.973 \pm 0.09^{c}$ & $2.316 \pm 0.10^{b}$ & $3.175 \pm 0.08^{\mathrm{a}}$ & 0.2707 & $1.76 \pm 0.11^{\mathrm{b}}$ & $2.143 \pm 0.13^{\mathrm{b}}$ & $2.79 \pm 0.16^{\mathrm{a}}$ & 0.4427 \\
\hline Life cycle & & $2.973 \pm 0.12^{\mathrm{c}}$ & $3.491 \pm 0.11^{\mathrm{b}}$ & $4.45 \pm 0.13^{\mathrm{a}}$ & 0.3439 & $2.76 \pm 0.14^{\mathrm{b}}$ & $3.268 \pm 0.13^{\mathrm{b}}$ & $3.99 \pm 0.18^{\mathrm{a}}$ & 0.5146 \\
\hline Longevity & & $18.5 \pm 0.52^{\mathrm{c}}$ & $22.33 \pm 0.33^{\mathrm{b}}$ & $24.27 \pm 0.79^{\mathrm{a}}$ & 1.871 & $20.3 \pm 0.56^{\mathrm{b}}$ & $23.50 \pm 0.76^{\mathrm{a}}$ & $25.2 \pm 0.66^{\mathrm{a}}$ & 1.838 \\
\hline Life span & & $21.47 \pm 0.55^{\mathrm{b}}$ & $25.82 \pm 0.36^{\mathrm{a}}$ & $26.13 \pm 0.79^{a}$ & 1.925 & $23.06 \pm 0.72^{\mathrm{c}}$ & $26.77 \pm 0.80^{b}$ & $29.19 \pm 0.69^{\mathrm{a}}$ & 2.034 \\
\hline
\end{tabular}

$\mathrm{A}=$ Active stage, $\mathrm{Q}=$ quiescent stage

Means in each columns followed by the same letter are not significantly different at $\mathrm{P} \leq 0.05 \% \pm$ Standard error.

Table (2): Effect of different diets on $H$. mahunkai female longevity and fecundity at $27{ }^{\circ} \mathrm{C} \pm 2$ and $85 \%+5$ R.H.

\begin{tabular}{lcccc}
\hline & & Diet & L.S.D & L.05 \\
\cline { 2 - 4 } Biological aspect & Dry yeast granules & Wheat germ & F.oxysporum & \\
\hline Pre-oviposition Period & $0.600 \pm 0.05^{\mathrm{a}}$ & $0.525 \pm 0.04^{\mathrm{a}}$ & $0.675 \pm 0.07^{\mathrm{a}}$ & 0.1654 \\
\hline Oviposition period & $14.200 \pm 0.42^{\mathrm{c}}$ & $17.500 \pm 0.43^{\mathrm{b}}$ & $19.100 \pm 0.77^{\mathrm{a}}$ & 1.584 \\
\hline Post-oviposition Period & $3.700 \pm 0.3^{\mathrm{a}}$ & $4.300 \pm 0.26^{\mathrm{a}}$ & $4.500 \pm 0.34^{\mathrm{a}}$ & 0.9536 \\
\hline Generation & $3.573 \pm 0.14^{\mathrm{c}}$ & $4.016 \pm 0.13^{\mathrm{b}}$ & $5.125 \pm 0.17^{\mathrm{a}}$ & 0.1305 \\
\hline Fecundity & $181.000 \pm 5.26^{\mathrm{a}}$ & $158.500 \pm 5.68^{\mathrm{b}}$ & $144.500 \pm 3.02^{\mathrm{b}}$ & 14.83 \\
\hline Daily Rate & $12.800 \pm 0.39^{\mathrm{a}}$ & $9.066 \pm 0.27^{\mathrm{b}}$ & $7.638 \pm 0.24^{\mathrm{c}}$ & 0.8261 \\
\hline
\end{tabular}

Means in each columns followed by the same letter are not significantly different at $\mathrm{P} \leq 0.05 \% \pm$ standard error.

Abou El-Atta et al. (2014) who mentioned that the life cycle of $C$. manure durated 7.42 days for female and tall days for male days at $30^{\circ} \mathrm{C}$; Eraky (1987) when reared $C$. berlesei (Mich.) on yeasted Dorosophila, the life cycle lasted 7.5 days at $26^{\circ} \mathrm{C}$; Woodring (1969) stated that life cycle of Caloglyphus anomalus averaged 6.5 days at $23^{\circ} \mathrm{C}$; whereas, Walia and Mathur (1998) indicated that Tyrophagous putrescentiae (Schrank) female life cycle durated 13.12 days when reared on juvenile of root the knot nematode (Meloidogyne javanica). Chmielewski (2000) reported that female $C$. berlesei life cycle was 19.90 days when fed on bee-bread, while in (2003) he found that its life cycle decreased to 17.7 days when reared on buck wheat sprouts at $20^{\circ} \mathrm{C}$ and $95-100 \%$ R.H. Also, Eraky and Osman (2008 b) reported that female and male C. manuri (Mich.) life cycle durated 10.40 and 8.10 days, respectively when reared on Meloidogyne sp. at $25^{\circ} \mathrm{C}$.

\section{Adult longevity:}

Longevity of females and males of H. mahunkai varied when fed on the different experimental food where significantly differences were recorded when fed on $F$. oxysporum took the longest period 24.270 days. This period changed to 22.330 and 18.500 days when fed on wheat germ and dry yeast granules, respectively with L.S.D. at 0.05 level $=0.3439$. while, for males no significant differences between individuals when fed on wheat germ and $F$. oxysporum but it shortest when fed on dry yeast granules, it registered 23.50, 25.20 and 25.20 days. These results illustrated that males lived longer than female. Similar data obtained by Abou El-Atta et al. (2014) who stated that the adult female lived for 27.20, 20.55 and 16.95 days while male lived for $16.85,18.40$ and 9.30 days20, 25 and $30^{\circ} \mathrm{C}$, respectively. Szlendak and Boczek (1992) showed that males of Acarus siro lived longer than females, since female lived about 15 days and male about 20 days at $25^{\circ} \mathrm{C}$ and $85 \%$ R.H. Moreover, Woodring (1969) recorded that C. anomalus average female lived for 23.4 and 18.5 days when fed on meal worms and yeast, respectively. Eraky and Osman (2008) stated that $C$. manure female lived 15.70, 11.60 and 17.80 days when fed on yeast, dry cheese and Meloidogyne sp., respectively.

\section{Pre-oviposition, oviposition and post-oviposition periods:}

Table (2) cleared that, $H$. mahunkai female began to deposit eggs after $0.600,0.525$ and 0.675 days when fed on dry yeast granules; wheat germ and $F$. oxysporum, respectively. Statistical analysis showed no significant differences between pre-oviposition period when reared on the food mentioned above with L.S.D. at 0.05 level $=0.1654$. 
The same table illustrated that, the oviposition period greatly increased when the mites fed on $F$. oxysporum (19.1 days) than on wheat germ (17.500 days) and dry yeast granules (14.200 days). Statistically, obtained data showed significant deference between individuals when fed on same trend of food with L.S.D. $0.05=1.584$. These results resemble Gerson et al. (1983) who examined the oviposition rates of $R$. robini grown on different diets and temperatures.

\section{Life span:}

Accordingly, the results in table (1) cleared that, $H$. mahunkai life span of was affected by the types of food. No significant differences in the life span of females fed on wheat germ and $F$. oxysporum $(25.820$, 26.130 days) while it significantly.

The statistical analysis in the same table showed there are significant differences on the life span between males when fed on dry yeast granules; wheat germ and $F$. oxysporum ( 23.06; 26.77 and 29.19 days, respectively). This result is supported by similar results on the same sub-order mentioned by Stearns, (1992) who illustrated the variation in the duration of each developmental stage and differences in transformation rates may be the result of the interplay between several environmental variables such as diet.

\section{Female fecundity:}

The diets suitability affected the number of deposited eggs by $H$. mahunkai adult. No significant difference was found between individuals fed on Wheat germ and $F$. oxysporum 158.500 and 144.500 eggs, respectively. However, when the mites fed on dry yeast granules the number of deposited eggs increased (181.000 eggs).

Gerson et al. (1983) reported that at $27{ }^{\circ} \mathrm{C} R$. robini females grown on peanuts laid 693 eggs per female over 40 days while those grown on garlic laid an average of 400 eggs per female over 31 days. Gravid females can carry a variable number of eggs (Woodring, 1969) which are laid one at a time and in a random fashion (Garman, 1937; Woodring, 1969). Oviposition is affected by many factors, including temperature and food quality. Woodring (1969) recorded that $C$. anomalus average female laid 930 and 545 eggs when fed on mealworms and yeast, respectively. Eraky and Osman $(2008 \mathrm{~b})$ stated that $C$. manure female of laid 601.40, 535.00 and 159.10 when fed on yeast, dry cheese and Meloidogyne sp., respectively. In 1987, Eraky found that $C$. berlesei deposited an average of 755.7 eggs in an average 15.9 days. Walia and Mathur (1998) found that $T$. putrescentiae (Schrank) female laid an average of 171.40 eggs when reared on juvenile of root the knot nematode (M. javanica). In 2000, Chmielewski showed that mean total deposited eggs per female of C. berlesei was 221.70 when fed on bee-bread where as in 2003, he recorded that its fecundity averaged 237.4 eggs when reared on buckwheat sprouts.

\section{Hypopal stage}

Hypopial stage of $\boldsymbol{H}$. mahunkai did not appear at any time under any condition. This resembled the findings of Eraky, (1992). Hughes (1976) who observed this result on T. putrescentiae (Schrank).

\section{ACKNOWLEDGMENTS}

I express my deep gratitude to the members of Shandaweel Agricultural Research Station for their help, support and cooperation. My great thanks to Prof. Dr. Sayed Eraky, Department of Plant Protection, Faculty of Agriculture, Assiut University, Assiut, Egypt for Identification of this specie and reviewing the manuscript. Also, I deeply thanks Dr. Hosam El-Gepaly, Researcher at Shandaweel Agricultural Research Station, plant protection Research Institute, A.R.C., for statistical analysis. Also, deep thanks to Mrs. Amany Elsayed, Assistant Researcher at Shandaweel Agricultural Research Station, Plant Pathology Research Institute, A.R.C., for Identification and provide me with $F$. oxysporum culture. My deep gratitude to Dr. A. M. Halawa (Fruit Acarology Department, Plant Protection Research Institute, A. R. C. for reviewing the manuscript.

\section{REFERENCES}

Abou El-Atta, D.A.; M.A.M. Genena and M.A. Osman 2014. Temperature Influence on Development and Life Table Parameters of the Acarid Mite, Caloglyphus manure Eraky \& Osman reared on the root-knot Nematode, Meloidogyne sp., ACARINES, 8 (1): 3-7.

Behura, B.K., 1957. The life history of Histiostoma polypore (Oud.) (Acari; Tyroglyphoidea). J. New York Entomol. Sci. 65: 51-78.

Bongers, M.G.H.; B.M. Oconnor and F.S. Lukoschus 1985. Morphology and Ontogeny of Histiostomatid mites (Acari: Astigmata) associated with cattle dung in the Netherlands. Zoologische Verhandelingen 223, 1:56.

Chmielewski, W., 1971a. Study on the influence of some ecological factors on the hypopus formation of stored product mites. Proc. $3^{\text {rd }}$ Inter. Congress Acarology Prague: 357-363.

Chmielewski, W., 1977. Powstawanie i znaczenie stadium hypopus $\mathrm{w}$ zyciu roztoczy $z$ nadrodziny Acaroidea. Prace Nauk. Inst. Ochr. Roslin 19: 5-94.

Chmielewski, W. 2000. Proba hodowli rozkruszka Caloglyphus berlesei (Michael) na pierzdze pszczelej. Materialy XVI Naukowej Konferencji 
warroza pszczol I gospodarka pasieczna, Olsztynkortowo: 8-10.

Chmielewski, W. 2003. Effect of buckwheat sprout intake on population increase of Caloglyphus berlesei (Michael) (Acari: Acaridae). Fagopyrum 20: 85-88.

Chmielewski, W. and U. Lipa, 1967. Biological and ecological studies on Caloglyphus mite (Acarina: Acaridae) associated with Scarabaeidae. Acta Paras it. Polon., v. 14, fasc. 18: 179-186.

Eraky, S.A. 1987. Observation on the biology of two species of acarid mites. Folia ent. Hung., 48: 21 27.

Eraky, S.A. 1992. Some biological aspects of Tyrophagus putrescentiae (Schrank) (Acari: Acaridae). Second Symposium of EURAAC, Krynica, Poland (First edition 1995): 197-204.

Eraky, S.A. 1994a. Three new anoetid mites extracted from animal excrement and from garlic (Acarina: Anoetidae). Folia Ent. Hung. 55: 217-223.

Eraky, S.A. 1994b. Two new hypopi of Histiostoma Kramer, 1876 (Acari: Astigmata) recovered from pomegranate and date fruits. Assiut J. Agric. Sci. 25 (2): 157-162.

Eraky, S.A. 1997. A key to new and old histiostomatid deutonymphs recorded in Assiut area with descriptions of two new species (Acari: Histiostomatidae). Assiut J. Agric. Sci. 28(1): 99-116.

Eraky, S.A. 1998. Mahunkagly phussolimani gen. and sp. n. and three new species (Acari: Astigmata) described from termite nests, western desert, Egypt. Folia Ent. Hung. 59: 241-250.

Eraky, S. A. 1999 a. A new genus and three new species of mites (Acari: Acaridida) phoretic on termites infesting the camphor trees in Aswan, Egypt. Annals hist.-nat. Mus.natu. hung. 91: 209-217.

Eraky, S.A. 1999 b. Five new hypopial nymphs (Acari: Acarididae and Histiostomatidae) described from different habitats. Folia ent. hung. 60: 45-56.

Eraky, S.A. 1999 c. Seven new species of mites (Acari: Acaridida) educed from different habitats in Upper Egypt. Assiut J. Agric. Sci. 30(5): 65-80.

Eraky, S.A. 2000 a. Identification key for some Acarididia mites (hypopi) (Acari: Astigmata) with descriptions of two new species. Assiut J. Agric. Sci. 31: 341-371.

Eraky, S.A. 2000 b. Morphological characters used in the taxonomy of the Acarididia mites. A Review Article Submitted to the Egyptian Scientific Committee for Promotion to Professorship, $66 \mathrm{pp}$.

Eraky, S.A. and N.I. Shoker, 1993 a. Mites extracted from uprooted banana sucker (Acari: Anoetidae). Folia. ent. hung. 54: 51-56.
Eraky, S.A. and N.I. Shoker, 1993 b. Description of two new anoetid mites (Acari: Anoetidae) collected from different habitats. Assiut J. Agric. Sci. 24(2): 233-241.

Eraky, S.A. and N.I. Shoker, 1994. Two new deutonymphs of the genus Histiostoma Kramer, 1876 (Acari: Histiostomatidae) existing in stored onions. Assiut J. Agric. Sci. 25(2): 163-168.

Eraky, S.A. and M.A. Osman, 2008a. Caloglyphus manuri sp. n. (Acaridida: Acaridae) extracted from chicken manure, Mansoura, Egypt. Acarines. 2: 43-44.

Eraky, S.A. and M.A. Osman, 2008b. Some biological aspects and life table parameters of Caloglyphus manuri Eraky \& Osman (Acaridida: Acaridae) fed on different kinds of food. ACARINES. 2: 45-48.

Eraky, S.A. and M.A. Osman, 2008c. New identification key for some Acaridides (Acaridida) from Upper Egypt, with description of a new Acaridae species. ACARINES. 2: 49- 60.

Eraky, S.A.; F.A. Abdel-Galil and M.K. Bohibah, 2010. Identification key for some phoretic acaridids (Acari: Acaridida) from Upper Egypt with description of two new species. Assiut J. Agric. Sci. 41(3): 76-92.

Eraky, S.A.; A.S. Abdelgayed; M.W. Negm; T.Y. Helal and S.F.M. Moussa, 2017. Two New Species of Histiostoma Kramer and Caloglyphus Berlese (Acari: Acaridida) from Citrus Orchards in Assiut, Egypt. Assiut J. Agric. Sci., (48) No. (1) 2017 (182-190).

Fain, A. \& Erteld, C. (1998). Description of a new species of Histiostoma Kramer, 1876 (Acari: Histiostomatidae) phoretic on the solitary bee Halictus sexcinctus (Fabricius, 1775) (Hymenoptera: Apidae: Halictinae).Bull. Annls Soc. R. Beige Ent. 134: 47-57.

Fakeer, M.; S.A. Eraky; M.A.I. Ahmed and A.S. Suleiman, 2014. Identification key for some acarid mites (Acari: Acaridae) extracted from termite nests with description of two new species. Assiut J. Agric. Sci. 45(2): 68-83.

Garman, P. 1937. A study of the bulb mite (Rhizoglyphus hyacinthi Banks). Bul 1. Conn. Agric. Exp. Sta. 402: 889-907.

Gerson, U., Capua, S. and Thorens, D. 1983. Life hi story and life tables of Rhizoglyphus robini Claparede (Acari: Astigmata: Acaridae). Acarologia 24: 439-448.

Hassan M.F; M.E. El-Naggar; A. E. Mesbah and R. A. El-Nahas 2014. Biological Aspects and Life Table Parameters of Cheletogenes ornatus (Canestrini\&Fanzago) (Acari:Cheyletidae) When Fed on Different Types of Food and temperatures. Jornal of Egyptian Society of Acarology. Vol, (8) No, (2): 31-35. 
Houck, M.A. and OConnor, B.M. 1991. Ecological and evolutionary significance of phoresy in the Astigmata. Annu. Rev. Entomol. 36: 611-636.

Hughes R.D. \& Jackson C.G. 1958. A review of the Anoetidae (Acari). Virginia J. Sci. 9, new serie (1): 5- 198.

Hughes, A. M., 1976. The mites of stored food and houses. Tech. Bull. Min. Agric. Fish. Food. 9, 400 pp.

Kazumi, T. and Yasumasa K. 2005. Remarkable species of histiostoma (Histiostomatidae, astigmata) from Japan with a pairof newly identified ventral coxal organsand sexual dimorphism of chemicals components. Acarologia, 45(1): 83-98.

Kuo, J. S. and H. H. J. Nesbitt 1970. Termination of the hypopial stage in Caloglyphus mycophagus (Megnin) (Acarina: Acaridae). Can. J. Zool. 48: $529-537$.

Kurosa,K. \& Tagami, K. 2006 Studies on histiostomid mites (Acari: Astigmata) associated with the burying beetle Nicrophorus concolor Kraatz (Coleoptera, Silphidae). Journal of Acarological Society of Japan 15 (2): 129 - 138.

Lipa, J.J. and W. Chmielewski 1966. Aparity observed in the development of Caloglyphus mite (Acarina: Acaridae). Ekol. Pol. A 14: 741-748.

Mahunka, S. 1972. Untersuchten Über taxonomische und systematische Probleme bei der Gattung Myianoetus Oudemans, 1913 und der Unterfamilie Myianoetidae (Acari, Anoetoidea). Ann. Hist.Nat. Mus. Natl. Hung. 64: 359-372.

Mašan P. and J. Krištofik 1992. Description of two species of the genus Myianoetus Oudemans, 1913 (Acarina, Anoetidae). Biologia 47: 81-85.

Muhammad, A.; Muhammad, S. \& Amjad A.W. 2000. Two new mite species (hypopi) of the genus Histiostoma on (Acari: Histiostomatidae) from Pakistan. Pak. J. Agri. Sci. Vol. 37(1-2).

OConnor, B.M. 2009. Cohort Astigmatina. In $A$ Manual of Acarology, 3rd edition (Eds, Krantz,
G.W. and Walter, D.E.), pp. 565-657.

OConnor, B.M. 1984. Nomenclatural status of some family-group names in the non psoroptidid Astigmata Acari: Acariformes, Internat. J. Acarol., 10: 203-207

Samšiňak K. 1989. Mites on flies of the family Sphaeroceridae. 2. Acarologia (Paris) 30 (2): 85-105.

Samšiňak, K. 1984. Mites on flies of the family Sphaeroceridae. Věst. Českoslov. Společ. Zool. 48: 45-63.

Scheucher R. 1957. Systematik und Ökologie der Deutchen Anoetinen, pp. 233-384. In: Stammer H.J. (eds), Beiträge zur Systematik und Ökologie mitteleuropäischer Acarina, Band I, Teil I, Akademische Verlagsgesellschaft Geest \& Portig K.-G., Leipizg, 384 pp.

Stearns, S.C. 1992. The Evolution of Life Histories. Oxford Univ. Press, Oxford.

Szlendak, E. and Boczek, J. 1992. Population development of the grain mite Acarus siro L. (Acari: Acaridae). Bulletin of the Polish Academy of Sciences / Biological Sciences, 40 (1): 73-79.

Vitzthum, H., 1943. Acarina (Bronns Klassen und Ordnungen des Tier- reichs, Bd. V, Abt. 4, Buch 5), Leipzig, $1011 \mathrm{pp}$.

Walia, K. K. and Mathur, S. 1998. Reproductive behavior of two nematophagous mites, nematodes and alternate diet. Ann. Pl. Protec. Sci., 6 (2): 178181.

Wallace D. R. J. 1960. Observations on hypopus development in the Acarina. J. Insect Physiol. 5: 216-229.

Woodring, J.P. 1969. Observations on the biology of six species of acarid mites. Ann. Ent. Soc. Am. 62: 102-108.

Zaher M.A.; A.E.A. Yousef and M.M. Kandil 1981. Effect of food on the biology of Cheletogenes ornatus (C. \& F.) [Acari: Prostigmata: Cheyletidae].Acarologia, 22, 4; 361-366. 